\title{
Nutrient limitation, organic matter cycling, and plankton dynamics during an Aureococcus anophagefferens bloom
}

\author{
Christopher J. Gobler ${ }^{1, *}$, George E. Boneillo ${ }^{1}$, Casey J. Debenham ${ }^{1}$, David A. Caron ${ }^{2}$ \\ ${ }^{1}$ Marine Science Program, Southampton College of Long Island University, Southampton, New York 11968, USA \\ ${ }^{2}$ University of Southern California, Department of Biological Sciences, 3616 Trousdale Parkway AHF 301, Los Angeles, \\ California 90089-0371, USA
}

\begin{abstract}
We evaluated plankton dynamics and the role of nutrients (organic and inorganic) during an intense $\left(>1.5 \times 10^{6} \mathrm{cells} \mathrm{ml}^{-1}\right)$ and sustained ( $\left.>4 \mathrm{mo}\right)$ brown tide bloom of the pelagophyte Aureococcus anophagefferens during the summer of 2000 in Great South Bay (GSB), New York, USA. During the study, light and dissolved inorganic nitrogen (DIN) levels were low (mean $1 \%$ light depth $=2 \mathrm{~m}$, mean DIN $=0.7 \mu \mathrm{M}$ ), while dissolved organic carbon and nitrogen levels were high (mean = 600 and $45 \mu \mathrm{M}$, respectively). Co-occurring with the $A$. anophagefferens bloom was a consortium of other small phytoplankton: $60 \pm 19 \%$ of chlorophyll present during the bloom was $<2 \mu \mathrm{m}$ and picocyanobacteria achieved densities $>10^{6}$ cells $\mathrm{ml}^{-1}$ following the peak of the brown tide. Although the growth of non-brown-tide phytoplankton, such as picocyanobacteria, was consistently enhanced by nitrate and urea additions (during $100 \%$ of experiments conducted, $\mathrm{n}=18$ ), the net population growth of $A$. anophagefferens was not stimulated by $\mathrm{N}$-enrichment in $60 \%$ of the experiments. During bloom initiation, decreases in DOC, DON, and DOP concentrations in GSB were similar to concurrent calculated increases in cellular $\mathrm{C}, \mathrm{N}$, and $\mathrm{P}$ of the burgeoning $A$. anophagefferens population, suggesting direct or indirect utilization of compounds within these pools by brown tide and associated microbes. In contrast, levels of DOM rose sharply when A. anophagefferens densities decreased and picocyanobacteria became the dominant phototrophs. These results illustrate a dichotomy in the algal communities of estuaries which host brown tides: often nitrogen-replete $A$. anophagefferens populations which are associated with DOM degradation and non-brown-tide phytoplankton populations such as picocyanobacteria which are consistently nitrogen-limited and associated with water column accumulation of DOM.
\end{abstract}

KEY WORDS: Harmful algal blooms - Brown tide - Aureococcus anophagefferens Nutrients · Cyanobacteria · Dissolved organic matter · Dissolved organic carbon · Dissolved organic nitrogen

\section{INTRODUCTION}

Harmful algal blooms (HABs) represent a significant threat to fisheries, public health, and economies around the world. The incidence of HABs has increased in recent years presumably due, in part, to inorganic nutrient enrichment of coastal zones (Smayda 1990, Anderson et al. 2002). Recently, it has been observed that some harmful algal species may also rely on dissolved organic matter (DOM) as a source of cellular nutrition to form blooms (Glibert et al. 2001, Anderson et al. 2002). Although much is known about the production of dissolved organic matter by phytoplankton (Mague et al. 1980, Kirchman et al. 1991, Williams 1995, Gobler \& Sañudo-Wilhelmy 2003), research investigating the importance of dissolved organic matter in promoting the occurrence of blooms is in its infancy.

One harmful algal species which has been associated with organically enriched estuarine conditions is 
the brown tide pelagophyte Aureococcus anophagefferens. For nearly 2 decades, brown tides have plagued estuaries within the mid-Atlantic US, disrupting shellfisheries and benthic habitats (Bricelj \& Lonsdale 1997). Laboratory cultures and field populations of $A$. anophagefferens have demonstrated its ability to assimilate organic carbon and nitrogen compounds (Dzurica et al. 1989, Berg et al. 2002, Mullholland et al. 2002). Field observations of brown tides indicate that blooms often occur when dissolved organic nitrogen (DON) levels are high (LaRoche et al. 1997, Gobler et al. 2002) or inorganic nitrogen levels are low (Keller \& Rice 1989, Gobler et al. 2002). Moreover, natural and manipulated inputs of dissolved organic nitrogen and carbon (DOC) have been observed to enhance the growth rates of $A$. anophagefferens during brown tide events (Gobler \& Sañudo-Wilhelmy 2001a,b). While $A$. anophagefferens cultures have demonstrated the ability to utilize dissolved organic phosphorus (DOP) compounds (Dzurica et al. 1989), the dynamics of DOP during a brown tide have yet to be described.

Aureococcus anophagefferens represents one of many small algal species which traditionally have been found within summer phytoplankton assemblages of Long Island embayments. During the 1950s, green tides of various pico-chlorophytes plagued many Long Island estuaries and contributed to the collapse of oyster fisheries (Ryther 1954). More recently, standing crops of chlorophyll in Long Island estuaries during summer months have been reported as almost exclusively in the $<5 \mu \mathrm{m}$ size fraction (Lonsdale et al. 1996, Gobler \& Sañudo-Wilhelmy 2001a). Sieracki et al. (1999) hypothesized that picocyanobacteria, such as Synechococcus sp., may compete with A. anophagefferens to fill a summer 'picoalgal-niche' in Long Island embayments. Since both picocyanobacteria and A. anophagefferens populations are similarly sized cells (1 to $2 \mu \mathrm{m}$ ), they may have similar nutrient uptake kinetics (Chisholm 1992), and thus may compete for nutritional resources. While a transition from cyanobacteria to A. anophagefferens dominance within Long Island estuarine phytoplankton communities during fall months has been documented previously (Gobler et al. 2002), the dynamics of these populations through a summer bloom event have not been reported.

To assess the relative importance of organic and inorganic nutrients to the growth of Aureococcus anophagefferens and other co-occurring small phytoplankton, an observational and experimental field campaign was established in Great South Bay, New York, during a brown tide in the summer of 2000. The dynamics of brown tide and picoplankton were documented along with levels of dissolved organic matter and inorganic nutrients. Nutrient addition experiments were conducted with organic (urea, glycine, glucose) and inorganic (nitrate, phosphate) nutrients to evaluate the response of $A$. anophagefferens, cyanobacteria, and the total phytoplankton community to these enrichments. The time series approach permitted observation of the role of nutrients and the dynamics of phytoplankton during the initiation, pinnacle, and demise of this intense brown tide event.

\section{MATERIALS AND METHODS}

Great South Bay (GSB) is a long $(40 \mathrm{~km})$, shallow $(2 \mathrm{~m})$, barrier island estuary located along the south shore of Long Island, New York, USA (Fig. 1). GSB is one of the most productive estuaries in the world (Lively et al. 1983), and has been plagued with brown tide blooms nearly every year since 1985 (Bricelj \& Lonsdale 1997). Our research was conducted during a brown tide event which occurred during May through September of 2000. We collected samples from a Boston whaler every 1 to $2 \mathrm{wk}$ from 31 May to 20 September from 2 sites in GSB: Patchogue Bay (PB), located in the eastern portion of GSB $\left(40^{\circ} 44^{\prime} 03^{\prime \prime} \mathrm{N}\right.$, $73^{\circ} 01^{\prime} 23^{\prime \prime} \mathrm{W}_{\text {; depth }}=4 \mathrm{~m}_{\text {; Fig. }}$ ), and Bay Shore Cove (BSC), located in the western portion of GSB $\left(40^{\circ} 42^{\prime} 08^{\prime \prime} \mathrm{N}, 73^{\circ} 14^{\prime} 12^{\prime \prime} \mathrm{W}\right.$; depth = 3 m; Fig. 1). On station, whole water was collected with a high-density polyethylene (HDPE) bucket and was transferred with minimal bubbling to three $20 \mathrm{l}$ polyethylene carboys kept in coolers during transport to the laboratory. The shallow, well-mixed nature of GSB (Wilson et al. 1991) ensured that sample water collected was representa-

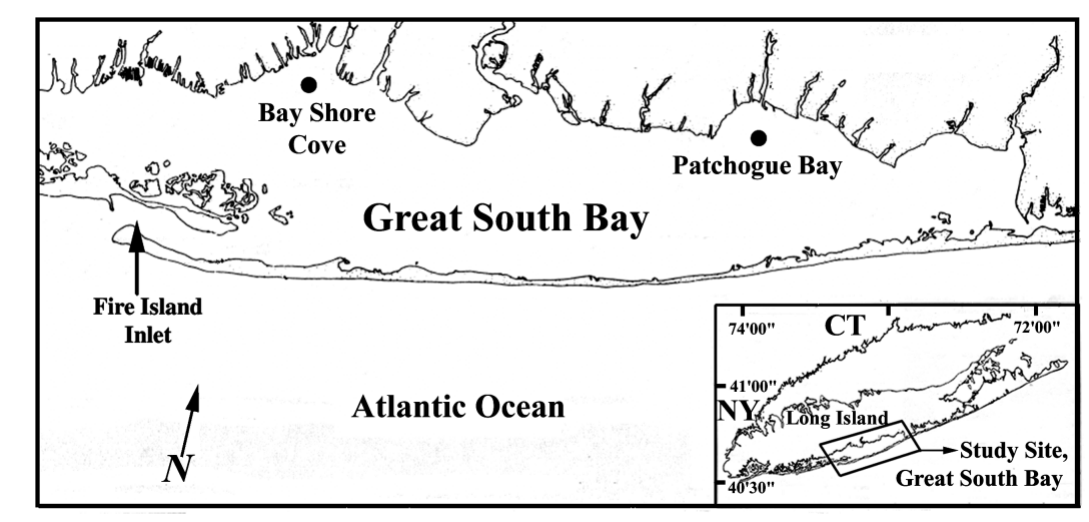

Fig. 1. Great South Bay, New York, USA, showing study sites Bay Shore Cove and Patchogue Bay 
tive of the entire water column at each station. Carboys, plastic buckets, and all other materials associated with the sampling, handling, and storage of seawater were acid-washed before use. Surface temperature and salinity were measured with a $\mathrm{YSI}^{\odot} 85$ probe and Secchi disk depths were also recorded. Field salinity measurements were confirmed by analysis of samples on a Beckman ${ }^{\odot}$ induction salinometer (Model RS 7B).

Filtered seawater $(0.2 \mu \mathrm{m})$ was generated in the field using a peristaltic pumping system (Gobler \& SañudoWilhelmy 2001a) from which organic nutrient, inorganic nutrient, and salinity samples were collected and immediately stored on ice. Within $1 \mathrm{~h}$ of collection, DOC samples were acidified with quartz-distilled nitric acid and frozen along with nutrient samples. Triplicate chlorophyll a (chl a) samples were collected on station using GF/F glass fiber filters (nominal pore size = $0.7 \mu \mathrm{m}$ ) and stored frozen. Chl a was also size-fractionated using $5 \mu \mathrm{m}$ Nitex $^{\odot}$ mesh and $2 \mu \mathrm{m}$ polycarbonate filters (Gobler \& Sañudo-Wilhelmy 2001a). Samples for the enumeration of cyanobacteria and Aureococcus anophagefferens were preserved to a final concentration of $1 \%$ glutaraldehyde in sterile polycarbonate test tubes using a $10 \%$ stock solution made from $0.2 \mu \mathrm{m}$ filtered GSB seawater. Samples for flow cytometric analysis were preserved with a $10 \%$ paraformaldehyde solution to a final concentration of $0.5 \%$.

Nutrient addition experiments were conducted to identify the type of nutrient regime that might promote brown tide proliferation. Within $1 \mathrm{~h}$ of collection, $1 \mathrm{l}$ of seawater was transferred to acid-clean 1.21 polycarbonate flasks. Triplicate flasks were amended with sodium nitrate $(10 \mu \mathrm{M})$, urea $(5 \mu \mathrm{M}=10 \mu \mathrm{M} \mathrm{N})$, glutamic acid $(10 \mu \mathrm{M}=10 \mu \mathrm{M} N)$, glucose $(17 \mu \mathrm{M}=$ $100 \mu \mathrm{M}$ C), phosphate $(1 \mu \mathrm{M})$, or were left unamended as a control treatment. The concentrations of these additions were similar to previously observed increases of these nutrients in the water column of GSB (Carpenter et al. 1991, Gobler et al. 2002). Nutrient stocks were filter-sterilized $(0.2 \mu \mathrm{m})$ and stored frozen. High levels of silicate ( 30 to $60 \mu \mathrm{M}$ ) in GSB during our experiments assured silicate-replete conditions for diatoms. Experimental bottles were incubated in situ at the Southampton College, Long Island University, Marine Station, located $40 \mathrm{~km}$ east of GSB (Gobler et al. 2002). Screening of bottles reduced ambient light penetration by $65 \%$. The average extinction coefficient in GSB during experiments was $2.3 \pm 0.6$ (based on Secchi disc readings); thus the light used in our experiments was similar to the light levels at $\sim 0.5 \mathrm{~m}$ in the GSB water column. After $24 \mathrm{~h}$, experimental flasks were processed for $\mathrm{chl} a$ and a $10 \mathrm{ml}$ aliquot was preserved to a final concentration of $1 \%$ glutaraldehyde for cell counts.
DOC samples were analyzed in duplicate by hightemperature catalytic oxidation using a Shimadzu TOC-5000 total organic carbon analyzer (Benner \& Strom 1993). Chl a was analyzed by standard fluorometric methods (Parsons et al. 1984). Standard spectrophotometric methods were used to analyze nitrate/nitrite (Jones 1984), ammonium, phosphate, and silicate (Parsons et al. 1984) in duplicate. Total dissolved nitrogen and phosphorus concentrations (TDN and TDP) were determined in duplicate using persulfate oxidation methods (Valderrama 1981). DON was calculated as the difference between TDN and dissolved inorganic nitrogen (nitrate, nitrite, ammonium), while DOP was calculated as the difference between TDP and orthophosphate. Measurements of intercalibration DOC samples (J. Sharp, University of Delaware) were within $6 \%$ of the consensus value. Analytical methods yielded full recoveries of inorganic (nitrate, ammonium and phosphate) and organic (total nitrogen and phosphorus) standard reference material.

Aureococcus anophagefferens densities were enumerated using a newly developed monoclonal antibody labeling technique based on an enzymelinked immunoabsorbant assay (ELISA) (Caron et al. 2003) and via the traditional polyclonal antibody technique (Anderson et al. 1989). The monoclonal antibody labeling technique was performed using 96-well microtiter plates and converted to abundance using a preserved culture of $A$. anophagefferens. Accurate abundances of $A$. anophagefferens can be obtained in natural samples with this technique to a lower threshold concentration of approximately $5 \times 10^{3}$ cells $\mathrm{ml}^{-1}$. No significant cross-reactions have been observed with a wide variety of co-occurring algae.

Cyanobacterial cells containing phycoerythrin Type II and phycocyanin were enumerated using epifluorescence microscopy (MacIsaac \& Stockner 1993, Gobler et al. 2002). The unicellular, $<1 \mu \mathrm{m}$ cells quantified with this filter set likely included phycoerythrin- and phycocyanin-containing cyanobacteria previously observed in GSB by Campbell et al. (1983) (e.g. Synechococcus sp. and Synechocystis sp.). These cells will be referred to simply as 'cyanobacteria' from this point onward (Gobler et al. 2002). A minimum of 200 cells was counted per sample in at least 10 fields to yield a coefficient of variation of $11 \%$ for replicate counts of the same sample $(n=10)$ at cell densities of $10^{6}$ cells $\mathrm{ml}^{-1}$. On the first 3 sampling dates of this project (31 May, 6 June, 13 June), the total number of suspended chl-a-containing and phycoerythrin-containing cells was quantified by T. Cucci (Bigelow Laboratories) using flow cytometry fluorescence patterns and particle size from forward angle light scatter as described by Newell et al. (1989). 
The amount of chl a due to the presence of brown tide in GSB was estimated from a range of chl a per cell values for Aureococcus anophagefferens (0.020 to $0.035 \mathrm{pg} \mathrm{cell}^{-1}$; Gobler 1995), and by multiplying this value by $A$. anophagefferens densities. Levels of chl a from picocyanobacteria were estimated from cell densities and published per cell chl a quotas (Kana \& Glibert 1987, Kudo \& Harrison, 1997). Although these calculations could introduce bias from variability in cellular chlorophyll concentrations due to changing light and nutrient levels, such approximations have been used successfully in the past to compare $A$. anophagefferens biomass to that of the total algal community (Gobler et al. 2002, Greenfield \& Lonsdale 2002). The relative abundance of $A$. anophagefferens or picocyanobacteria within the phytoplankton community was calculated as a percentage of total phytoplankton biomass: A. anophagefferens or picocyanobacteria chl a/total chl a) $\times 100$.

Net growth rates of Aureococcus anophagefferens, cyanobacteria, and the total phytoplankton community during bottle incubations were calculated from changes in cell densities and chl a using the formula: $\mu=\left[\ln \left(B_{t} / B_{0}\right)\right] / t$, where $\mu$ is the net growth rate, $B_{t}$ is the amount of biomass (cell density or chl a) present at the end of the experiments, $B_{0}$ represents the amount of biomass at the beginning of experiments, and $t$ is the duration of the experiment in days.

\section{RESULTS}

\section{Physical characteristics of the water column}

During the summer of 2000, temperatures in BSC and PB were similar and followed an expected seasonal trend, rising from $<20^{\circ} \mathrm{C}$ during late May and early June to a peak of $\sim 26^{\circ} \mathrm{C}$ in late June and early July, and then decreasing steadily to $\sim 20^{\circ} \mathrm{C}$ by September (Table 1). Salinities did not show a discernable seasonable trend, but were slightly higher in BSC $\left(26.4 \pm 1.2 \mathrm{PSU}_{\text {; }}\right.$ Table 1) than in PB (24.5 $\pm 0.2 \mathrm{PSU}_{\text {; }}$ Table 1). The degree of light penetration through the water column of BSC and $\mathrm{PB}$ was similar; the mean $1 \%$ light depth in GSB (PB and BSC mean) was $1.6 \pm 0.3 \mathrm{~m}$ during May and June, but increased to $2.4 \pm 0.2 \mathrm{~m}$ during July to September (Table 1).

\section{Plankton dynamics}

During late May and June 2000, an intense phytoplankton bloom developed throughout Great South Bay. Chl a levels in GSB increased from moderate levels $\left(\sim 20 \mu \mathrm{g} \mathrm{l}^{-1}\right)$ in late May to a 26 June peak of $36 \pm$

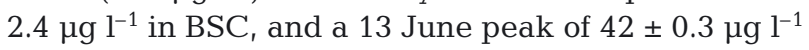
in PB (Figs. 2A \& 3A). Following this peak, chl a concentrations steadily decreased, varying between 13 and $23 \mu \mathrm{g} \mathrm{l}^{-1}$ during July and August, and dropping to $5.5 \pm 1.0$ and $11 \pm 1.1 \mu \mathrm{l}^{-1}$ in $\mathrm{BSC}$ and $\mathrm{PB}$ on 20 September. Size fractionation of chlorophyll indicated that the majority of the phytoplankton biomass in BSC throughout this study was $<2 \mu \mathrm{m}(66 \pm 6 \%$; Fig. 2A). Although a similar trend was observed in $\mathrm{PB}$ during May to July ( $75 \pm 11 \%$ of chlorophyll $<2 \mu \mathrm{m})$, August and September observations indicated a more even distribution of chlorophyll among the $>5 \mu \mathrm{m}(19 \pm$ $10 \%), 2$ to $5 \mu \mathrm{m}(36 \pm 9 \%)$ and $<2 \mu \mathrm{m}(45 \pm 9 \%)$ size classes in PB (Fig. 3A).

Aureococcus anophagefferens and picocyanobacteria were dominant among the small phytoplankton in GSB during the summer of 2000. In BSC, A. anophagefferens densities steadily increased from $5.1 \times 10^{5}$ cells ml ${ }^{-1}$ on 31 May to peak densities of $1.5 \times$

Table 1. Physical and chemical measurements made in Great South Bay (GSB) in summer 2000. BSC: Bay Shore Cove; PB: Patchogue Bay; $1 \%$ light: $1 \%$ light depth calculated from the extinction coefficient; DIN: dissolved inorganic nitrogen; DIP: dissolved inorganic phosphorus; DSi: silicate. Nutrient data are means (SD)

\begin{tabular}{|lcccccc|}
\hline Date & $\begin{array}{c}\mathrm{T} \\
\left({ }^{\circ} \mathrm{C}\right)\end{array}$ & $\begin{array}{c}\text { S } \\
(\mathrm{PSU})\end{array}$ & $\begin{array}{c}1 \% \text { light } \\
(\mathrm{m})\end{array}$ & $\begin{array}{c}\text { DIN } \\
(\mu \mathrm{M})\end{array}$ & $\begin{array}{c}\text { DIP } \\
(\mu \mathrm{M})\end{array}$ & $\begin{array}{c}\text { DSi } \\
(\mu \mathrm{M})\end{array}$ \\
\hline BSC & & & & & & \\
31 May & 19.5 & 26.16 & 2.0 & $0.78(0.21)$ & $0.14(0.02)$ & $7.58(0.91)$ \\
7 Jun & 19.0 & 25.61 & 2.2 & $0.67(0.12)$ & $0.20(0.00)$ & $10.8(0.77)$ \\
13 Jun & 22.3 & 24.63 & 1.9 & $0.97(0.18)$ & $0.23(0.01)$ & $10.3(4.34)$ \\
26 Jun & 25.9 & 26.30 & 1.4 & $0.22(0.15)$ & $0.24(0.03)$ & $32.0(4.07)$ \\
6 Jul & 25.7 & 27.47 & 2.3 & $0.34(0.13)$ & $0.18(0.02)$ & $39.6(0.83)$ \\
20 Jul & 24.1 & 28.77 & 2.4 & $0.87(0.15)$ & $0.62(0.01)$ & $37.7(0.76)$ \\
2 Aug & 24.6 & 27.05 & 2.4 & $0.52(0.22)$ & $0.80(0.01)$ & $38.6(2.26)$ \\
22 Aug & 21.8 & 26.21 & 2.6 & $0.63(0.16)$ & $0.60(0.02)$ & $47.2(0.64)$ \\
13 Sep & 20.6 & 25.40 & 2.7 & $0.84(0.25)$ & $0.49(0.04)$ & $40.9(10.8)$ \\
Mean & $22.6(2.60)$ & $26.4(1.23)$ & $2.2(0.4)$ & $0.65(0.25)$ & $0.39(0.24)$ & $29.4(15.4)$ \\
PB & & & & & & \\
31 May & 16.2 & 24.50 & 1.5 & $1.25(0.26)$ & $0.07(0.00)$ & $10.9(1.68)$ \\
7 Jun & 18.5 & 24.08 & 1.5 & $0.81(0.25)$ & $0.10(0.01)$ & $13.8(0.19)$ \\
13 Jun & 21.0 & 24.45 & 1.4 & $0.82(0.24)$ & $0.05(0.02)$ & $22.3(5.74)$ \\
26 Jun & 25.9 & 24.39 & 1.4 & $0.30(0.04)$ & $0.12(0.10)$ & $38.3(0.57)$ \\
6 Jul & 26.1 & 24.65 & 2.4 & $0.28(0.12)$ & $0.30(0.00)$ & $49.2(7.87)$ \\
20 Jul & 24.2 & 24.85 & 2.4 & $0.95(0.11)$ & $1.12(0.09)$ & $60.5(0.49)$ \\
2 Aug & 24.3 & 24.60 & 2.2 & $1.22(0.22)$ & $0.88(0.00)$ & $70.1(1.73)$ \\
22 Aug & 22.7 & 24.51 & 2.2 & $0.61(0.11)$ & $0.79(0.05)$ & $74.7(0.21)$ \\
13 Sep & 20.4 & 24.50 & 2.7 & $0.66(0.21)$ & $0.77(0.06)$ & $59.1(0.76)$ \\
Mean & $22.1(3.39)$ & $24.5(0.21)$ & $2.0(0.5)$ & $0.77(0.35)$ & $0.47(0.42)$ & $44.3(24.1)$ \\
GSB & & & & & & \\
Mean & $22.4(3.00)$ & $25.5(1.30)$ & $2.1(0.5)$ & $0.71(0.32)$ & $0.43(0.33)$ & $33.2(19.0)$ \\
\hline
\end{tabular}



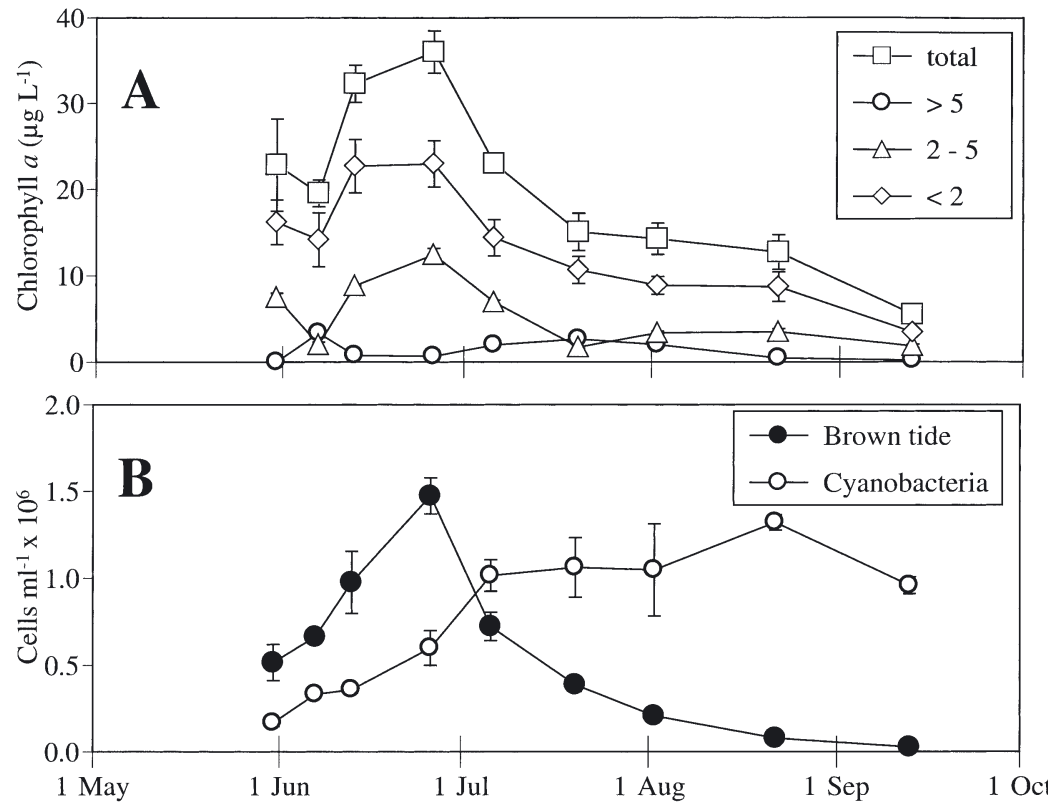

Fig. 2. Variation in (A) size-fractionated (total, $>5 \mu \mathrm{m}, 2$ to $5 \mu \mathrm{m}$, and $<2 \mu \mathrm{m}$ ) chlorophyll $a$, and (B) Aureococcus anophagefferens and cyanobacterial cell densities in Bay Shore Cove during summer 2000. Error bars represent \pm 1 SD of triplicate measurements

$10^{6} \mathrm{cells} \mathrm{ml}^{-1}$ on 26 June, while cyanobacterial densities increased from $1.6 \times 10^{5}$ to $6.0 \times 10^{5}$ cells ml $^{-1}$ during the same period (Fig. 2B). Flow cytometry revealed that the BSC community gradually approached a bi-specific community during this time, as the non- $A$. anophagefferens/non-cyanobacteria community decreased from 40 to $3 \%$ of fluorescent particles enumerated by flow cytometry from 31 May to 13 June (Table 2). Following the brown tide bloom peak, $A$. anophagefferens densities in BSC were reduced by about half on each subsequent sampling date, with concentrations $>10^{5}$ cells $\mathrm{ml}^{-1}$ being sustained through August (Fig. 2B). In contrast, cyanobacteria reached and sustained peak densities of $\sim 1 \times 10^{6}$ cells ml $^{-1}$ in BSC through July, August and September. A. anophagefferens remained dominant during July (up to $100 \%$ of algal biomass), but represented a less significant portion of the algal community during subsequent sampling dates (30 to $52 \%$ on 2 August, 11 to $20 \%$ on 22 August, and 9 to $16 \%$ on 20 September; Table 2). Cyanobacteria were notable components of the phytoplankton community in BSC during July and August (21 to $47 \%$ of total biomass;
Table 2), and experienced an increase in relative abundance on the final sampling date (50 to $80 \%$; Table 2 ).

In $\mathrm{PB}$, Aureococcus anophagefferens densities increased from $1.0 \times 10^{6}$ cells ml $^{-1}$ on 31 May to a peak of $1.4 \times 10^{6}$ cells ml $^{-1}$ on 13 June, as cyanobacteria simultaneously increased from $1.4 \times 10^{5}$ to $3.7 \times 10^{5}$ cells ml ${ }^{-1}$ (Fig. 3B). Flow cytometry and chlorophyll estimations indicated that these 2 taxa accounted for $101 \pm 5 \%$ of phytoplankton cells from 31 May to 13 June (Table 2). A. anophagefferens abundances subsequently decreased through the end of June, and sustained levels of $\sim 1.5 \times$ $10^{5}$ cells ml ${ }^{-1}$ in July, while cyanobacterial levels increased more than 4 -fold during the same period. Following a peak of $1.6 \times 10^{6}$ cells ml $\mathrm{m}^{-1}$ on 20 July, cyanobacterial levels in PB gradually declined to $9 \times 10^{5}$ cells ml ${ }^{-1}$ on 20 September, while $A$. anophagefferens remained at $\sim 5 \times 10^{4}$ cells $\mathrm{ml}^{-1}$ during this period (Fig. 3B). A. anophagefferens represented 15 to $46 \%$ of the phytoplankton community in July and only 6 to $18 \%$ of the community in August and September (Table 2). Concurrently, the cyanobacteria population in PB represented 27 to $60 \%$ of the total phytoplankton community in July and 17 to $40 \%$ of the total community in August and September (Table 2).
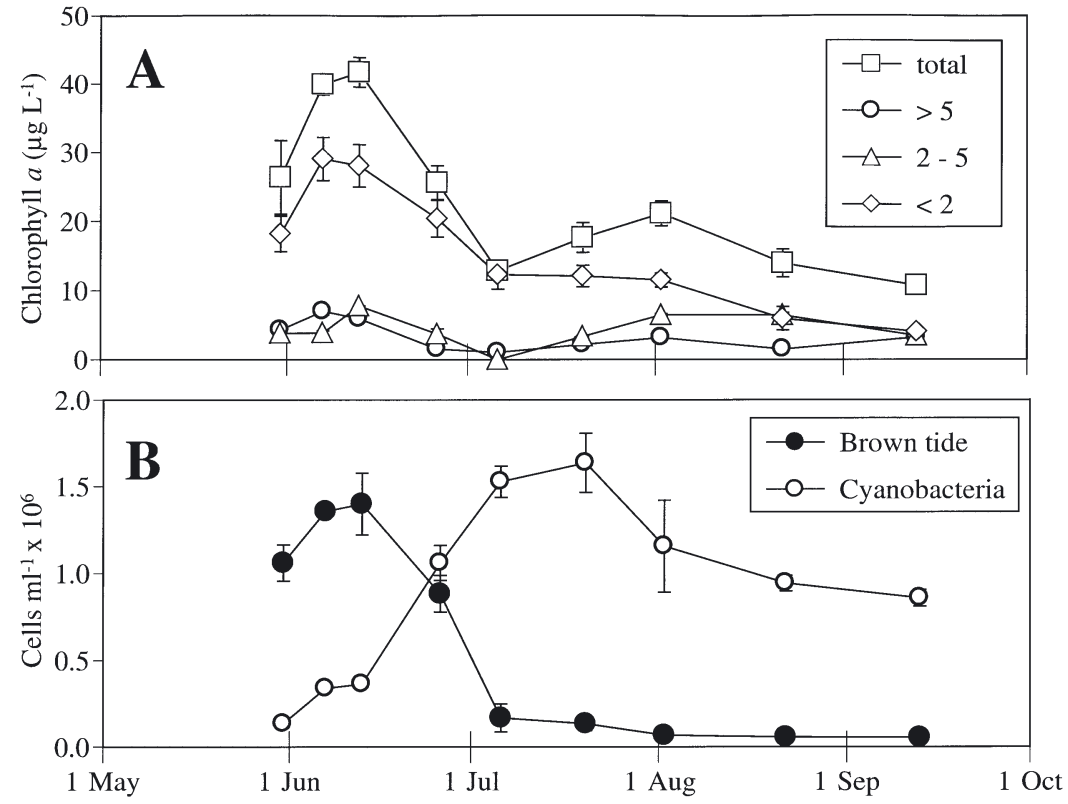

Fig. 3. Variation in (A) size-fractionated (total, $>5 \mu \mathrm{m}, 2$ to $5 \mu \mathrm{m}$, and $<2 \mu \mathrm{m}$ ) chlorophyll a, and (B) Aureococcus anophagefferens and cyanobacterial cell densities in Patchogue Bay during summer 2000. Error bars represent \pm 1 SD of triplicate measurements 
Table 2. Aureococcus anophagefferens and cyanobacteria. Absolute and relative abundance in Great South Bay, summer 2000. Total chl a: total chlorophyll a $\left(\mu \mathrm{g} \mathrm{l}^{-1}\right)$; BT: A. anophagefferens cell densities $\mathrm{ml}^{-1}$ determined by immunofluorescent detection; Cyano: number of picoplanktonic cyanobacteria $\mathrm{ml}^{-1}$ determined by microscopy; \% Cyano-chl a: percent total chlorophyll presumably represented by picophytoplanktonic cyanobacteria; \% BT-chl a: percent total chlorophyll presumably represented by A. anophagefferens; Total cells: total number of chlorophyll a fluorescing particles $\mathrm{ml}^{-1}$; Syn: number of picoplanktonic particles ml ${ }^{-1} \mathrm{contain}^{-}$ ing phycoerythrin (probably Synechococcus sp.) determined by flow cytometry; Other: number of total fluorescent particles ml ${ }^{-1}$ not accounted for by Synechococcus sp. or A. anophagefferens; \% BT: percent total cells enumerated by flow cytometry attributable to $A$. anophagefferens; \% Syn: percent total fluorescent particles attributable to Synechococcus sp.; \% other: percent total fluorescent particles unaccounted for by Synechococcus sp. or A. anophagefferens; -: dates when flow cytometry was not performed

\begin{tabular}{|c|c|c|c|c|c|c|c|c|c|c|c|}
\hline Date & Total chl a & BT & Cyano & \% Cyano-chl a & $\%$ BT-chl a & Total cells & Syn & Other & $\%$ BT & \% Syn & $\%$ other \\
\hline \multicolumn{12}{|l|}{ BSC } \\
\hline 31 Мay & 20 & 516000 & 169000 & $2.5-4.2$ & $52-90$ & 1140000 & 175468 & 451000 & 45 & 15 & 40 \\
\hline 7 Jun & 20 & 665000 & 334000 & $5.0-8.3$ & $66-110$ & 1260000 & 315371 & 282000 & 53 & 25 & 22 \\
\hline 13 Jun & 33 & 977000 & 361000 & $3.5-5.5$ & $59-100$ & 1340000 & 321911 & 40300 & 73 & 24 & 3.0 \\
\hline 26 Jun & 36 & 1470000 & 600000 & $12-30$ & $80-140$ & - & - & - & - & - & - \\
\hline $6 \mathrm{Jul}$ & 23 & 724000 & 1020000 & $23-39$ & $62-110$ & - & - & - & - & - & - \\
\hline $20 \mathrm{Jul}$ & 15 & 389000 & 1060000 & $21-35$ & 51-91 & - & - & - & - & - & - \\
\hline 2 Aug & 14 & 210000 & 1050000 & $22-37$ & $30-52$ & - & - & - & - & - & - \\
\hline 22 Aug & 14 & 79000 & 1320000 & $28-47$ & $11-20$ & - & - & - & - & - & - \\
\hline 13 Sep & 6.0 & 28500 & 958000 & $50-80$ & $9.0-16$ & - & - & - & - & - & - \\
\hline \multicolumn{12}{|l|}{ PB } \\
\hline 31 May & 26 & 1000000 & 136000 & $1.5-2.6$ & $81-140$ & 1170000 & 105000 & 4540 & 91 & 8.9 & 0.39 \\
\hline 7 Jun & 40 & 1360000 & 340000 & $2.6-4.3$ & $70-120$ & 1700000 & 302000 & 42900 & 80 & 18 & 2.50 \\
\hline 13 Jun & 42 & 1400000 & 365000 & $2.6-4.3$ & $70-120$ & 1620000 & 297000 & 0.0 & 86 & 18 & 0.0 \\
\hline 26 Jun & 22 & 883000 & 1060000 & $15-24$ & $80-140$ & - & - & - & - & - & - \\
\hline $6 \mathrm{Jul}$ & 13 & 169000 & 1530000 & $35-59$ & $26-46$ & - & - & - & - & - & - \\
\hline $20 \mathrm{Jul}$ & 18 & 136000 & 1640000 & $27-45$ & $15-26$ & - & - & - & - & - & - \\
\hline 2 Aug & 21 & 68200 & 1160000 & $17-28$ & $6-11$ & - & - & - & - & - & - \\
\hline 22 Aug & 13 & 57600 & 944000 & $22-36$ & $8.9-16$ & - & - & - & - & - & - \\
\hline $13 \mathrm{Sep}$ & 11 & 55600 & 859000 & $23-39$ & $10-18$ & - & - & - & - & - & - \\
\hline
\end{tabular}

\section{Organic and inorganic nutrient levels}

Nutrient pools in GSB during the summer of 2000 followed 3 distinct trends. The dissolved inorganic nitrogen (DIN) pool during this study was small and variable, as concentrations averaged $0.71 \pm 0.32 \mu \mathrm{M}$ and ranged from 0.22 to $1.25 \mu \mathrm{M}$ (Table 1). Dissolved inorganic phosphate and silicon concentrations displayed a steady, seasonal rise from lower levels at the beginning of the summer (31 May to 6 July, DIP $=0.16 \pm$ $0.08 \mu \mathrm{M}, \mathrm{DSi}=23 \pm 15 \mu \mathrm{M}$, Table 1 ) to higher levels at the end of the summer (20 July to 20 September, DIP = $0.76 \pm 0.20 \mu \mathrm{M}, \mathrm{DSi}=54 \pm 15 \mu \mathrm{M}$; Table 1). A third nutrient trend was illustrated by organic nutrient pools, which were high during the study and showed a significant decrease in concentrations during the month of June and a sharp increase during July and August. Specifically, mean levels of DON $(47 \pm 12 \mu \mathrm{M})$ were more than 50 -fold greater than DIN, mean levels of DOP $(1.84 \pm 0.86 \mu \mathrm{M})$ were $5 \times$ greater than DIP, and mean DOC levels were also quite high $(580 \pm 120 \mu \mathrm{M}$; Figs. 4 \& 5). Within the DON pool, urea was only a minor component $\left(0.27 \pm 0.14 \mu \mathrm{M}_{i}\right.$ data not shown). The size of the dissolved organic pools changed in parallel with the onset and demise of Aureococcus anophagefferens blooms in GSB. For example, as brown tide cell densities in BSC increased from $5 \times 10^{5}$ cells ml ${ }^{-1}$ on 31 May to $1.5 \times 10^{6}$ cells ml ${ }^{-1}$ on 26 June, DOC levels decreased $90 \mu \mathrm{M}$ from 520 to $430 \mu \mathrm{M}$, DON levels decreased by $20 \mu \mathrm{M}$ from 47 to $27 \mu \mathrm{M}$, and DOP decreased $\sim 1 \mu \mathrm{M}$ from $1.68 \mu \mathrm{M}$ to $0.67 \mu \mathrm{M}$ (Fig. 4). The dynamics of $A$. anophagefferens cells and organic nutrient pools were similar during the initiation of the Patchogue Bay brown tide bloom. For example, from 31 May to 7 June, A. anophagefferens cell densities in Patchogue Bay increased from $1.0 \times 10^{6}$ to $1.4 \times 10^{6}$ cells ml $^{-1}$ and concurrently DOC decreased $40 \mu \mathrm{M}$ from 680 to $640 \mu \mathrm{M}$, DON decreased $9 \mu \mathrm{M}$ from 47 to $38 \mu \mathrm{M}$ and DOP decreased $\sim 1 \mu \mathrm{M}$ from 1.79 to $0.77 \mu \mathrm{M}$ (Fig. 5). As the A. anophagefferens bloom began to decay and cyanobacterial densities increased during July, organic nutrient pools increased dramatically and remained elevated through August (Figs. 4 \& 5). Specifically, in BSC, levels of DOC, DON, and DOP increased by 55,89 , and $290 \%$ from late June to early August, achieving concentrations of $670 \pm 29.9,64.3 \pm$ 0.26 , and $2.61 \pm 0.03 \mu \mathrm{M}$, respectively, on 2 August (Fig. 4). Similarly, in PB, levels of DOC, DON, and DOP increased by 72,84 and $150 \%$ from mid-June to early August, achieving concentrations of $864 \pm 21.3,65.0 \pm$ 0.56 , and $3.62 \pm 0.03 \mu \mathrm{M}$, respectively, on 2 August (Fig. 5). 

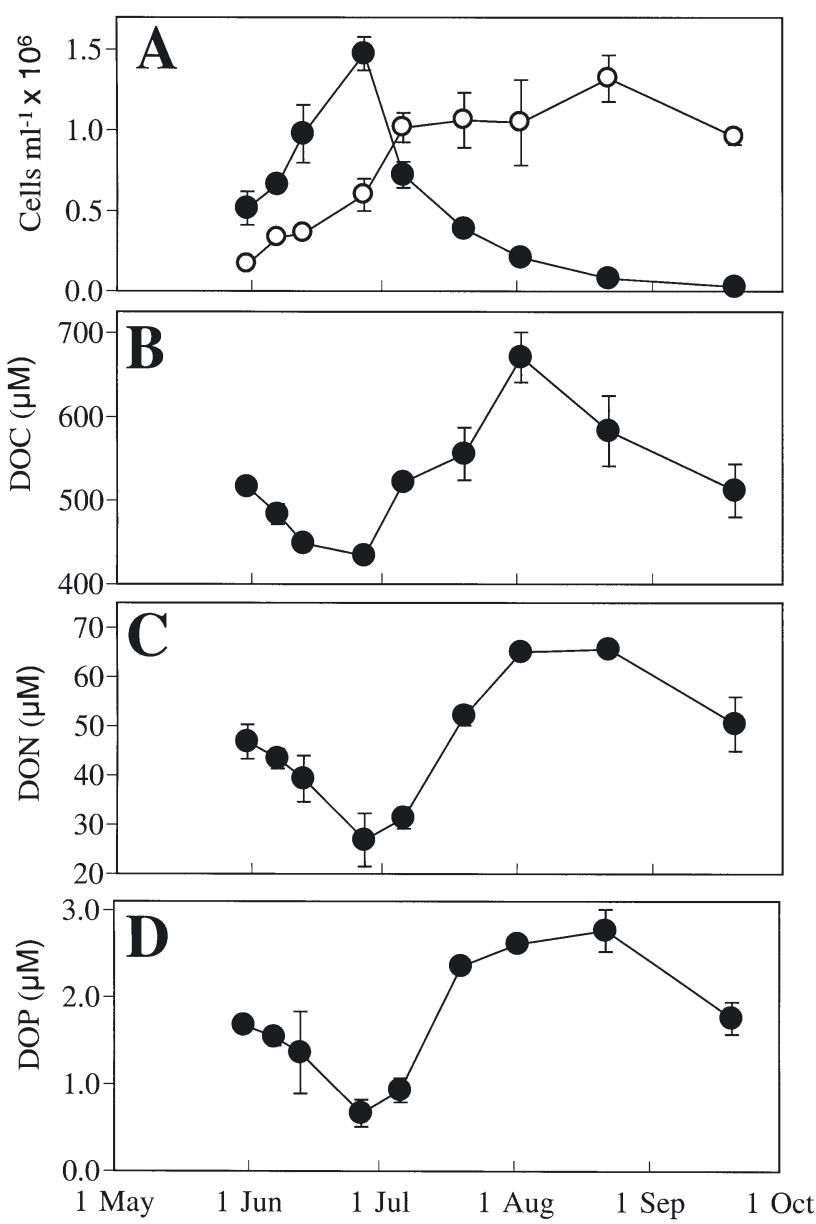

Fig. 4. Changes in (A) Aureococcus anophagefferens (-) and cyanobacteria cell densities (O), (B) DOC, (C) DON, and (D) DOP in Bay Shore Cove during summer 2000. Error bars represent $\pm 1 \mathrm{SD}$ of triplicate (cell densities) or duplicate (DOM) measurements

\section{Nutrient addition experiments}

During all 18 experiments (9 in $\mathrm{BSC}, 9$ in $\mathrm{PB}$ ) conducted throughout the summer of 2000, the net growth rates of the total phytoplankton assemblage and cyanobacteria populations in GSB were enhanced significantly above unamended controls by additions of simple nitrogen compounds, such as nitrate and/or urea (Figs. $6 \& 7 ; \mathrm{p}<0.05$; Student's $t$ test). Specifically, nitrate significantly enhanced total phytoplankton net growth rates above control treatments during 15 of 18 experiments (Figs. 6 \& 7; p < 0.05 ; $t$-test), with 3 late-summer experiments (BSC: 2 August and 20 September; PB: 20 September) being the only exceptions. Nitrate additions also yielded cyanobacterial net growth rates that were significantly greater than control treatments during 15 of 18 experiments (Figs. $6 \& 7_{;} \mathrm{p}<0.05 ; t$-test), with nitrate and control growth rates being statistically equal in BSC on 31 May and in PB on 13 June and 6 July (Figs. 6 \& 7). Urea significantly enhanced total phytoplankton growth rates beyond control treatments during 14 of 18 experiments (Figs. 6 \& 7; p < 0.05 ; $t$-test), with the first 2 experiments in BSC (31 May, 7 June) and 2 mid-summer PB experiments (13 June, 6 July) being the exceptions. Cyanobacteria displayed a somewhat less consistent response to urea additions, experiencing significantly enhanced $(\mathrm{p}<0.05)$ growth rates relative to controls in BSC on 31 May, 13 June, 6 July, 20 July, and 20 September, and in PB on 31 May, 13 June, 20 July, 22 August and 20 September (10 out of 18 experiments; Figs. 6 \& 7). Finally, glutamic acid additions yielded significantly increased growth relative to controls for the total phytoplankton population in BSC on 31 May
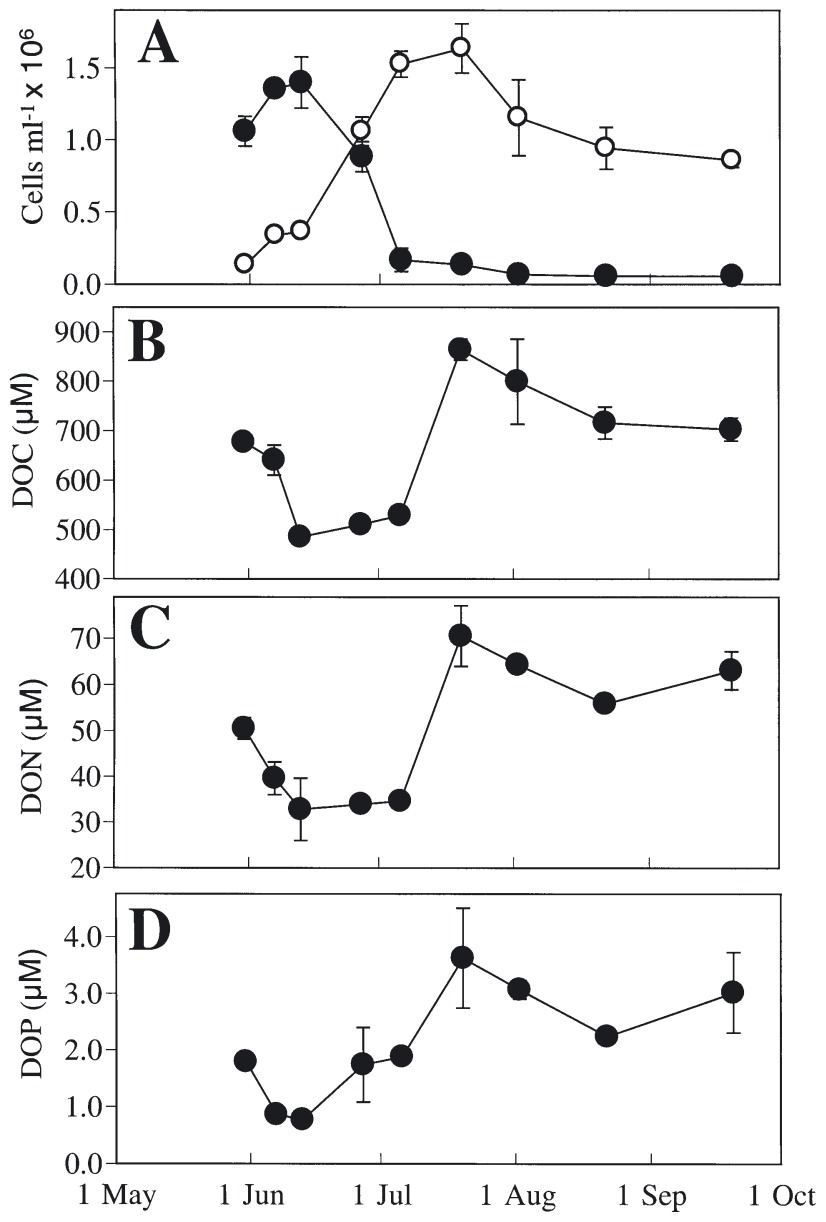

Fig. 5. Changes in (A) Aureococcus anophagefferens (-) and cyanobacteria cell densities (O), (B) DOC, (C) DON, and (D) DOP in Patchogue Bay during summer 2000. Error bars represent $\pm 1 \mathrm{SD}$ of triplicate (cell densities) or duplicate (DOM) measurements 


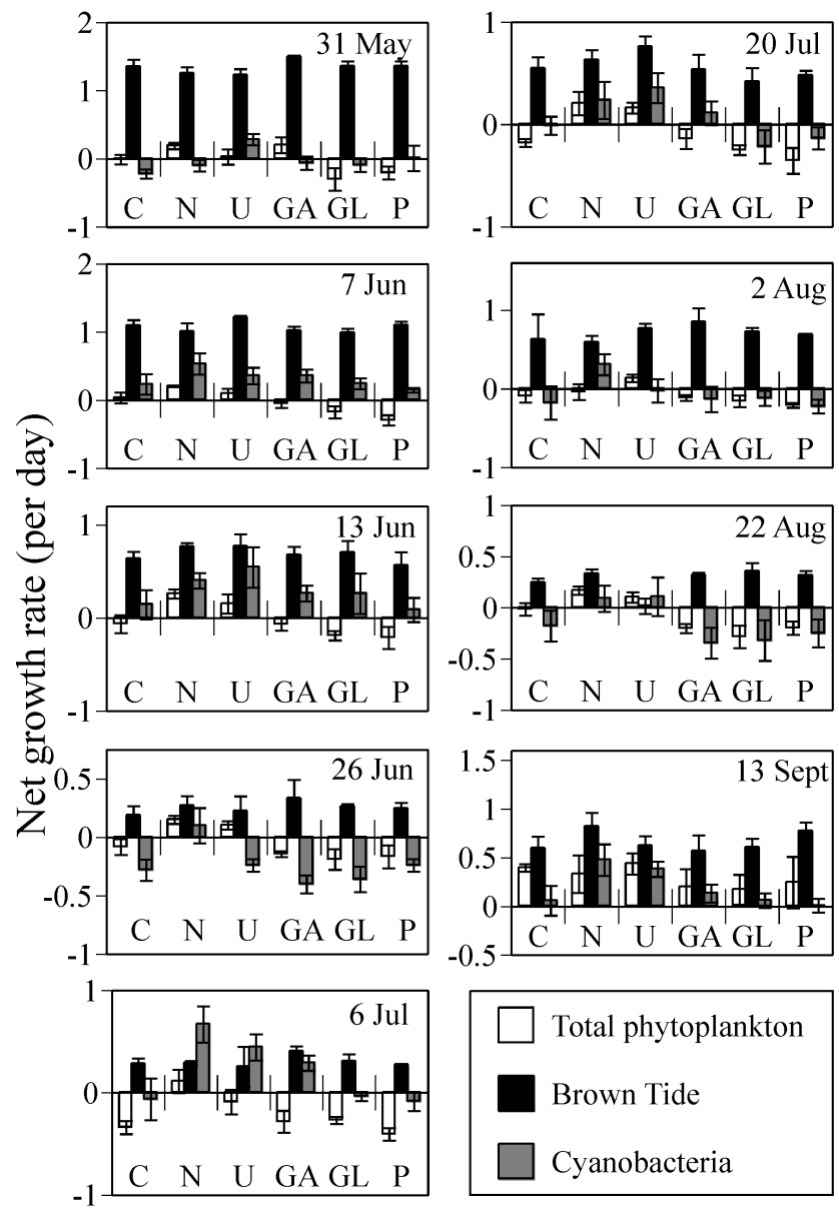

Fig. 6. Net growth rates of total phytoplankton (white bars), brown tide (Aureococcus anophagefferens; black bars), and cyanobacteria (gray bars) during experiments using water from Bay Shore Cove. C: control; N: nitrate; U: urea; GA: glutamic acid; GL: glucose; P: phosphate. Error bars represent \pm 1 SD of triplicate measurements

and in PB on 6 July, and for cyanobacteria in BSC on 6 July and in PB on 20 July (Figs. 6 \& 7; p $<0.05$; $t$-test). Phosphate and glucose additions did not enhance growth rates of the total phytoplankton community (i.e. chl a-specific growth rates) or cyanobacteria relative to unamended controls (Figs. 6 $\& 7)$.

In contrast to the total phytoplankton community and cyanobacteria growth rates, Aureococcus anophagefferens growth rates were stimulated less frequently by nitrogen additions (8 of 18 experiments), and displayed a response which differed between BSC and PB (Figs. 6 \& 7). The A. anophagefferens population in BSC responded only occasionally to $\mathrm{N}$-additions, experiencing enhanced growth rates relative to controls due to glutamic acid on 31 May, 6 July, and 22 August, due to urea on 7 June, and due to nitrate on 13 June (Fig. $6 ; \mathrm{p}<0.05$; $t$-test). The BSC A. anophagefferens population did not respond to any nutrient additions during 4 of 9 experiments (27 June, 20 July, 2 August, and 20 September; Fig. 6). In $\mathrm{PB}$, only phosphorus additions increased $A$. anophagefferens growth rates relative to controls during the early stages of the bloom (31 May and 13 June; Fig. $7 ; \mathrm{p}<0.05$; t-test). During midsummer, A. anophagefferens populations in PB responded to additions of nitrogen and carbon, as nitrate significantly enhanced growth rates on 27 June and 6 July (Fig. 7 ; p $<0.05$; t-test), urea and glucose each significantly enhanced growth rates on 6 July and 20 July (Fig. $7 ; \mathrm{p}<0.05 ; t$-test), and glutamic acid enhanced growth rates on 6 July (Fig. $7 ; \mathrm{p}<0.05 ; t$-test). The PB A. anophagefferens population showed no response to nutrient additions during 4 of 9 experiments ( 7 June, 2 August, 22 August, 20 September; Fig. 7).

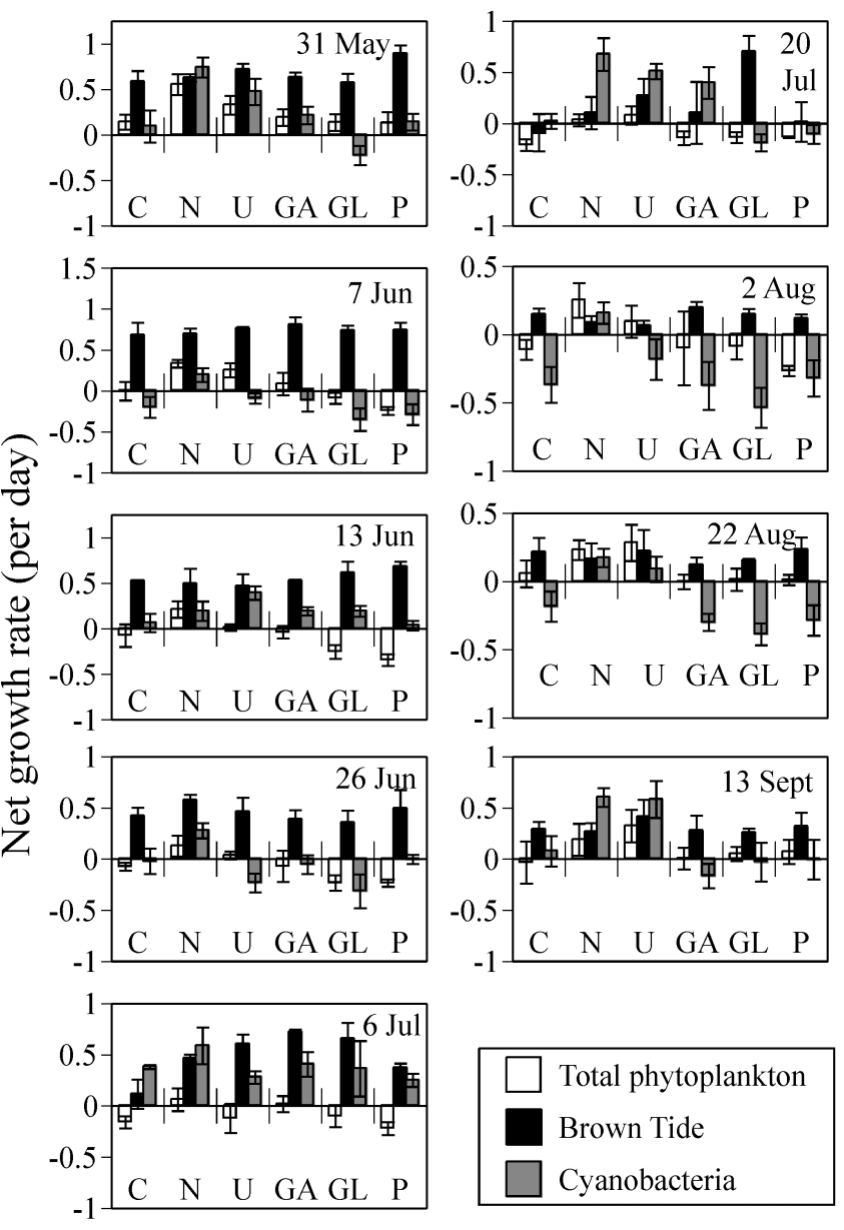

Fig. 7. Net growth rates of total phytoplankton (white bars), brown tide (Aureococcus anophagefferens; black bars), and cyanobacteria (gray bars) during experiments using water from Patchogue Bay. Further details as in Fig. 6 


\section{DISCUSSION}

The Aureococcus anophagefferens bloom that occurred in GSB during the summer of 2000 was the most intense and geographically extensive since its first recorded occurrence there in 1985, when densities also reached $\sim 1.5 \times 10^{6} \mathrm{cells} \mathrm{ml}^{-1}$ and extended across the entire latitudinal gradient of the estuary (SCDHS 1985-2000). This bloom was also remarkable in its duration and impacts. Cell densities in western GSB (BSC) remained above levels known to inhibit shellfish feeding $\left(3.5 \times 10^{4}\right.$ cells ml $^{-1}$; Bricelj et al. 2001) during our entire 4 mo study (Fig. 2B), and two-thirds of juvenile bivalves experimentally placed in GSB during this bloom experienced mortality (Greenfield \& Lonsdale 2002). Our experimental and observational results revealed a dichotomy in phytoplankton-nutrient interactions in GSB. While non-brown-tide phytoplankton populations such as cyanobacteria were consistently nitrogen-limited and were associated with water column production of DOM, A. anophagefferens populations were frequently $\mathrm{N}$ replete and were associated with DOM degradation. The dualistic nature of these phytoplankton groups lends insight into the role of nutrients in the occurrence of $A$. anophagefferens blooms.

\section{Pico-phytoplankton communities}

Co-occurring with the summer 2000 Aureococcus anophagefferens bloom in GSB was a consortium of other small phytoplankton, most notably picocyanobacteria (Figs. $2 \& 3$ ). Consistent with this view, the majority of algal biomass present was $<2 \mu \mathrm{m}$ (Figs. 2A \& 3A). Previously, Sieracki et al. (1999) hypothesized that $A$. anophagefferens and cyanobacteria may compete with each other to fill a 'picoalgal niche' in estuaries where brown tides occur. Some, but not all, our observations were consistent with this hypothesis. In the present study, these 2 groups of algae accounted for most of the phytoplankton present and, during the early stages of this bloom, when flow cytometry was utilized, nearly $100 \%$ of the picocyanobacteria quantified microscopically were phycoerythrin-containing Synechococcus sp. (Table 2: comparison of Syn and Cyano counts). In addition, a succession of dominant algae from $A$. anophagefferens during June to cyanobacteria during the months of July and August was also noted (Figs. 2B \& 3B). As in other ecosystems around the world, cyanobacterial abundances in the present study were correlated with water temperature in GSB throughout the summer of $2000\left(\mathrm{r}^{2}=0.57 ; \mathrm{p}<\right.$ 0.001; Krempin \& Sullivan 1981, Caron et al. 1985, Waterbury et al. 1986). Thus, seasonal increases in the abundance of cyanobacteria in GSB may be constrained initially by temperature rather than by direct competition for limiting nutrients with the brown tide alga. It is possible that direct competition between the brown tide alga and cyanobacteria could occur later in the summer, and affects the succession from dominance of the phytoplankton assemblage by $A$. anophagefferens to dominance by cyanobacteria.

These observations do not, however, explain the dominance of Aureococcus anophagefferens during the early summer over a wide variety of microalgae with which it co-occurs. In this respect, it is possible that the availability of organic nutrient sources promoted the growth of $A$. anophagefferens at this time (Figs. 4 to 7 ; see also next subsection). If brown tide growth waned as the more labile fraction of these sources was depleted, and net cyanobacterial growth concurrently increased with bay temperatures, the observed succession could be explained without invoking a competition for nutrients or the contribution of other factors. However, it is probable that differential grazing on $A$. anophagefferens and cyanobacteria by microbial consumers also plays an important role in determining the relative abundance of these 2 taxa (Gobler et al. 2002). Collectively (rather than via nutrient competition per se) these factors may explain shifts in dominance among these 2 tiny phototroph populations.

\section{Nutrient dynamics}

The extremely high levels of phytoplankton biomass

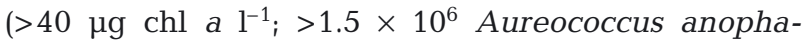
gefferens cells ml ${ }^{-1}$; $>1.5 \times 10^{6}$ cyanobacteria cells $\mathrm{ml}^{-1}$ ) during the summer of 2000 in GSB clearly created substantial cellular demands for nutrients. Obtaining these elements by traditional autotrophic means was likely to have been challenging for algal communities. Concentrations of DIN were low $\left(<1 \mu \mathrm{M}_{i}\right.$ Table 1$)$, suggesting that $\mathrm{N}$-supply could have been limiting algal growth (Caperon \& Meyer 1972). Additionally, the $1 \%$ light depth during the early stages of the bloom averaged $\sim 1.5 \mathrm{~m}$ (Table 1 ), indicating that net positive photosynthetic carbon assimilation could have occurred in less than half of the total water column (Harris 1980, Yentsch 1980). With such large demands for $\mathrm{C}$ and $\mathrm{N}$ and with the prevailing light and nutrient regimes being less than optimal for traditional autotrophic acquisition of $\mathrm{C}$ and $\mathrm{N}$, experimental nutrient additions were expected to have had a substantial impact on the growth rates of phytoplankton in GSB. Consistent with this view, total phytoplankton and cyanobacteria net growth rates appeared to be Nlimited, as both populations consistently (in 100\% of 
experiments) experienced significantly enhanced net growth rates relative to control treatments during experimental additions of nitrate and/or urea (Figs. 6 \& 7), a response expected for phytoplankton within New York estuaries (Ryther \& Dunstan 1971, Gobler et al. 2002). In contrast to these communities, nitrate and/or urea failed to enhance $A$. anophagefferens net growth rates during the majority $(60 \%)$ of experiments conducted (Figs. 6 \& 7). This finding is consistent with previous research, which has indicated that DIN loading generally decreases the relative abundance of $A$. anophagefferens within the phytoplankton community (Gobler \& Sañudo-Wilhelmy 2001a, Gobler et al. 2002). Interestingly, the more complex nitrogen compound, glutamic acid, significantly enhanced growth rates of the total phytoplankton and cyanobacteria populations (11\% of experiments) less frequently than A. anophagefferens ( $22 \%$ of experiments; Figs. $6 \& 7$ ). This could potentially be due to the alga's relatively high affinity for amino acid uptake (Mulholland et al. 2002). Since both picocyanobacteria and $A$. anophagefferens cells are similarly sized (1 to $2 \mu \mathrm{m}$ ), they could have similar nutrient uptake kinetics (Chisholm 1992), and one might hypothesize that they compete for nutrients during blooms (see preceding subsection). However, the differential response of $A$. anophagefferens and cyanobacteria to nutrients during this study (Figs. 4 to 7 ) suggests that these populations rely on different nutrient sources for growth and thus may not compete for nutritional resources during brown tides.

In contrast to nitrogen, additions of phosphate increased the net growth rate of Aureococcus anophagefferens during the bloom initiation period in PB (31 May, 13 June; Fig. 7). Phosphate additions had a similar impact on $A$. anophagefferens net growth rates during the initiation of brown tide during the fall of 1999 in PB (Gobler et al. 2002). In a manner similar to that fall bloom event, the ambient nutrient regime, the physiology of $A$. anophagefferens, and the biogeochemistry of $\mathrm{P}$ in shallow estuaries may have all contributed toward the P limitation of brown tide growth during these experiments. Although the DIN:DIP ratio in PB during late May and early June was similar to the Redfield ratio (14 \pm 5.3 ; 31 May to 13 June), the TDN:TDP ratio was well above it $(40 \pm 12)$. Consistent with our experimental results (Fig. 7), these ratios suggest that autotrophic algae using strictly inorganic sources might have been nutrient-replete or N-limited, but that mixotrophs such as $A$. anophagefferens, which may access both organic and inorganic nutrients, could have been P-limited. The sudden increase in orthophosphate in GSB during late June and July (Table 1) may be an indication of enhanced benthic P-flux due to a change in redox state of sediments in this shallow estuary (Boynton \& Kemp 1985). This $P$ source likely alleviated any P-limitation of brown tide on subsequent dates during the summer of 2000 in PB (Figs. 6 \& 7). Interestingly, mean DIN:DIP $(4.4 \pm 1.1)$ and TDN:TDP $(24 \pm 3.6)$ ratios in BSC were both substantially lower than PB during late May and early June, and P-limitation was not observed in any algal community in BSC during this study. Future research examining seasonal variability in sediment oxygen levels and nutrient fluxes in conjunction with $A$. anophagefferens densities might assist in elucidating the role of benthic nutrient fluxes in bloom dynamics.

The ability of Aureococcus anophagefferens to frequently grow nutrient-replete $(50 \%$ of experiments; Figs. 6 \& 7), despite its large cellular demand for $C, N$, and $\mathrm{P}$ and the low ambient light levels and low inorganic nutrient concentrations in GSB, may have been due to its reliance on ambient organic nutrient pools for growth (Figs. 4 \& 5). Substantial declines in DOC, DON, and DOP concentrations during $A$. anophagefferens bloom initiation (June) suggested utilization of compounds within these organic pools (LaRoche et al. 1997). To determine what portion of $A$. anophagefferens' cellular requirement could have been satisfied by the observed reductions in organic carbon, nitrogen, and phosphorus pools (Table 3), mass balance calculations of these elements were calculated. In BSC, brown tide cell densities increased from $5 \times 10^{5}$ cells ml $^{-1}$ on 31 May to $1.5 \times 10^{6}$ cells ml $^{-1}$ on 26 June - an increase of $10^{6}$ cells ml ${ }^{-1}$. An application of $A$. anophagefferens' cellular C quota $\left(1.8 \times 10^{-13} \mathrm{~mol} \mathrm{C} \mathrm{cell}^{-1}\right.$; Gobler et al. $1997)$ to the observed change in cell densities $\left(10^{6}\right.$ cells $\mathrm{ml}^{-1}$ ) indicates a $\mathrm{C}$ requirement of $180 \mu \mathrm{M}$ for this

Table 3. Mass balance of Aureococcus anophagefferens cellular carbon, nitrogen, and phosphorus during the 2000 GSB brown tide bloom

\begin{tabular}{|c|c|c|c|c|c|c|c|c|c|}
\hline \multirow[t]{2}{*}{ Area } & \multicolumn{3}{|c|}{ Bloom requirement $(\mu \mathrm{M})$} & \multicolumn{3}{|c|}{ Observed DOM decrease $(\mu \mathrm{M})$} & \multicolumn{3}{|c|}{$\%$ of cellular requirement $(\mu \mathrm{M})$} \\
\hline & $\mathrm{C}$ & $\mathrm{N}$ & $\mathrm{P}$ & $\mathrm{C}$ & $\mathrm{N}$ & $\mathrm{P}$ & $\mathrm{C}$ & $\mathrm{N}$ & $\mathrm{P}$ \\
\hline $\begin{array}{l}\text { Bay Shore Cove } \\
31 \text { May to } 26 \text { Jun }\end{array}$ & 180 & 24 & 1.5 & 90 & 20 & 1.0 & 50 & 83 & 67 \\
\hline $\begin{array}{l}\text { Patchogue Bay } \\
31 \text { May to } 7 \text { Jun }\end{array}$ & 73 & 9.0 & 0.60 & 40 & 9.0 & 1.0 & 55 & 100 & 160 \\
\hline
\end{tabular}


bloom. Similarly, the cellular N demand of this bloom would have been $24 \mu \mathrm{M}$ based on the species' cellular $\mathrm{N}$ quota $\left(2.4 \times 10^{-14} \mathrm{~mol} \mathrm{~N}\right.$ cell $^{-1}$; Gobler et al. 1997 and present Table 3). In Patchogue Bay, the smaller cell density increase during bloom initiation $\left(4 \times 10^{5}\right.$ cells $\mathrm{ml}^{-1}$ from 31 May to 7 June) would have created a smaller demand for $\mathrm{C}$ and $\mathrm{N}(73 \mu \mathrm{M} \mathrm{C}$ and $9 \mu \mathrm{M} \mathrm{N})$ compared to BSC (Table 3). Although the cellular $\mathrm{P}$ content of $A$. anophagefferens has not been established, a Redfield ratio extrapolation of cellular $\mathrm{C}$ and $\mathrm{N}$ contents would indicate a cellular requirement of $1.5 \times 10^{-15} \mathrm{~mol} \mathrm{P}$ cell $^{-1}$. Such a cellular quota would have generated a population demand for P in BSC and $\mathrm{PB}$ of 1.5 and $0.60 \mu \mathrm{M}$, respectively (Table 3 ).

These cellular elemental requirements are within the range of observed reductions in DOC, DON, and DOP pools in GSB during the summer 2000 brown tide. The $20 \mu \mathrm{M}$ reduction in the DON pool at BSC during bloom initiation could have accounted for $83 \%$ of Aureococcus anophagefferens' cellular $\mathrm{N}$ requirement (Table 3). In contrast, the observed $90 \mu \mathrm{M}$ reduction in DOC and $1.0 \mu \mathrm{M}$ reduction in DOP in BSC would have accounted for 50 and $67 \%$ of the brown tide's cellular $\mathrm{C}$ and $\mathrm{P}$ requirements, respectively (Table 3 ). While the $9 \mu \mathrm{M}$ DON decline during the initiation of the PB bloom was equivalent to the cellular nitrogen requirement of this bloom $(9 \mu \mathrm{M})$, simultaneous decreases in DOC and DOP were below and above the levels required by $A$. anophagefferens (Table 3 ).

The observed dynamics of DOC, DON, DOP and Aureococcus anophagefferens cell densities (Figs. 4 \& 5) characterize brown tides as net consumers of DOM and suggest that $A$. anophagefferens relies on organic DOM pools to supply a portion of its cellular C, N, and $P$. There is ample field and laboratory evidence within the literature which indicates that $A$. anophagefferens could have utilized DOM compounds in these pools via direct assimilation or via peptide hydrolysis and subsequent assimilation of associated inorganic compounds (Berg et al. 2002, 2003, Mullholland et al. 2002). Alternatively, heterotrophs associated with this bloom could have remineralized DOM to forms which were subsequently utilized by $A$. anophagefferens or other microbes, as an increase in inorganic nutrients was not observed during DOM degradation. Further support of the hypothesis that phytoplankton communities dominated by $A$. anophagefferens are net consumers of DOM can be gleaned from the cyanobacteriadominated community that succeeded the brown tide. During July and August, when cyanobacteria were the dominant algal class (Table 2), levels of DOC, DON, and DOP rose sharply in BSC and PB (Figs. 4 \& 5), a pattern which is consistent with previous observations of phytoplankton blooms in New York estuaries (Gobler \& Sañudo-Wilhelmy 2001b, Mulholland et al.
2002) and other marine environments (Williams 1995, Kahler \& Koeve 2001) during summer months. Since our experimental results show that cyanobacteria seem to thrive on inorganic nitrogen (Figs. 6 \& 7), remineralization of DON by heterotrophic bacteria (at a rate slower than DON production) following the decline of A. anophagefferens could have liberated ammonium, which was subsequently used by cyanobacteria to promote their abundance.

While reductions in DON during brown tide initiation have been observed during previous Aureococcus anophagefferens blooms (LaRoche et al. 1997), this study documents decreases in DOC levels for the first time (Figs. 4B \& 5B). The remarkably high net growth rates $\left(>1 \mathrm{~d}^{-1}\right.$; Figs. $\left.6 \& 7\right)$ and cell densities $\left(>10^{9} \mathrm{l}^{-1}\right.$; Figs. 2 \& 3) observed during the initiation of this bloom were both likely to have contributed to the ability of the bloom to impact concentrations of DOM pools. If the DOC declines in GSB during the present study were indicative of organic carbon utilization by $A$. anophagefferens, this would be consistent with the observed enhancement of brown tide growth by the addition of organic carbon containing compounds such as glucose, urea, and glutamic acid during some experiments (Figs. 6 \& 7; and Gobler \& Sañudo-Wilhelmy 2001a). This finding is also consistent with previous research, which has demonstrated $A$. anophagefferens' ability to utilize organic carbon from DOM (Dzurica et al. 1989, Mullholland et al. 2002). The ability of $A$. anophagefferens to supplement its photosynthetic C-fixation with heterotrophic uptake of DOC may have given the brown tide an advantage over strictly autotrophic species, particularly given the low light conditions which persisted in GSB during the summer of 2000 ( $1 \%$ light depth $<2 \mathrm{~m}$; Table 1$)$.

Acknowledgements. This project was supported by awards from NOAA-ECOHAB (NA16OP2790 to C.J.G. and D.A.C.) and New York Sea Grant (R/CMB-26 to C.J.G.). We thank Terry Cucci and Mike Sieracki for assistance with flow cytometry analysis of samples. We thank Southampton College marine science students Nate Buck, Marc Renaghan, Matthew Donoghue, Tim Comstock, Nikki Remington, Joanna Bilz, Sabrina Alvarado, and Dave Anderson, as well as Dan Skelly, for assistance during field sampling, experiments and analyses. We thank the Southampton College Marine Station for boat usage and assistance and the Fire Island National Seahore's Patchogue facility for boat mooring space.

\section{LITERATURE CITED}

Anderson DM, Kulis DM, Cosper EM (1989) Immunofluorescent detection of the 'brown tide' organism, Aureococcus anophagefferens. Coast Estuar Stud 35:213-228

Anderson DM, Glibert PM, Burkholder JM (2002) Harmful algal blooms and eutrophication: nutrient sources, composition and consequences. Estuaries 25:704-726 
Benner R, Strom M (1993) A critical evaluation of the analytical blank associated with DOC measurements by hightemperature catalytic oxidation. Mar Chem 41:153-160

Berg GM, Repeta DJ, Laroche J (2002) Dissolved organic nitrogen hydrolysis rates in axenic cultures of Aureococcus anophagefferens (Pelagophyceae): comparison with heterotrophic bacteria. Appl Environ Microbiol 68: 401-404

Berg GM, Repeta DJ, Laroche J (2003) The role of the picoeukaryote Aureococcus anophagefferens in cycling of marine high-molecular weight dissolved organic nitrogen. Limnol Oceanogr 48:1825-1830

Boynton WR, Kemp WM (1985) Nutrient regeneration and oxygen consumption by sediments along an estuarine salinity gradient. Mar Ecol Prog Ser 23:45-55

Bricelj VM, Lonsdale DJ (1997) Aureococcus anophagefferens: causes and ecological consequences of brown tides in U.S. mid-Atlantic coastal waters. Limnol Oceanogr 42: 1023-1038

Bricelj VM, MacQuarrie SP, Schaffner RA (2001) Differential effects of Aureococcus anophagefferens isolates ('brown tide') in unialgal and mixed suspensions on bivalve feeding. Mar Biol 139:605-615

Campbell L, Carpenter EJ, Iacono VJ (1983) Idenification and enumeration of marine chroococcoid cyanobacteria by immunofluorescence. Appl Environ Microbiol 46:553-559

Caperon J, Meyer J (1972) Nitrogen-limited growth of marine phytoplankton. II. Uptake kinetics and their role in nutrient growth of phytoplankton. Deep-Sea Res 19:619-632

Caron DA, Pick FR, Lean DRS (1985) Chroococcoid cyanobacteria in Lake Ontario: vertical and seasonal distributions during 1982. J Phycol 21:171-175

Caron DA, Schaffner RA, Moran DM, Dennett MR, Lonsdale DJ, Gobler CJ, Nuzzi R, McLean TI (2003) Development and application of a monoclonal antibody technique for counting Aureococcus anophagefferens, an alga causing recurrent brown tides in the Mid-Atlantic United States. Appl Environ Microbiol 69:5492-5502

Carpenter EJ, Brinkhuis BM, Capone DG (1991) Primary production and nitrogenous nutrients in Great South Bay. In: Schubel JR, Bell TM, Carter HH (eds) The Great South Bay. State University of New York Press, Albany, p 33-42

Chisholm SW (1992) Phytoplankton size. In: Falkowsi PG, Woodhead AD (eds) Primary production and biogeochemical cycles in the sea. Plenum Press, New York, p 213-237

Dzurica S, Lee C, Cosper EM, Carpenter EJ (1989) Role of environmental variables, specifically organic compounds and micronutrients, in the growth of chrysophyte Aureococcus anophagefferens, the 'brown tide' microalage. Coast Estuar Stud 35:229-252

Glibert PM, Magnien R, Lomas MW, Alexander J, Fan CK, Haramoto E, Trice M, Kana TM (2001) Harmful algal blooms in the Chesapeake and coastal bays of Maryland, USA: comparison of 1997, 1998, and 1999 events. Estuaries 24:875-883

Gobler CJ (1995) The role of iron in the occurrence of Aureococcus anophagefferens blooms. Masters thesis, State University of New York at Stony Brook

Gobler CJ, Sañudo-Wilhelmy SA (2001a) Effects of organic carbon, organic nitrogen, inorganic nutrients, and iron additions on the growth of phytoplankton and bacteria during a brown tide bloom. Mar Ecol Prog Ser 209:19-34

Gobler CJ, Sañudo-Wilhelmy SA (2001b) Temporal variability of groundwater seepage and brown tide blooms in a Long Island embayment. Mar Ecol Prog Ser 217:299-309

Gobler CJ, Sañudo-Wilhelmy SA (2003) Cycling of colloidal organic carbon and nitrogen during estuarine plankton blooms. Limnol Oceanogr 48:2314-2320

Gobler CJ, Hutchins DA, Fisher NS, Cosper EM SañudoWilhelmy SA (1997) Release and bioavailability of C, N, P, $\mathrm{Fe}$, and Se following viral lysis of a marine chrysophyte. Limnol Oceanogr 42:1492-1504

Gobler CJ, Buck NJ, Renaghan MJ (2002) Impacts of nutrients and grazing mortality on the abundance of Aureococcus anophagefferens during a New York brown tide bloom. Limnol Oceanogr 47:129-141

Greenfield DI, Lonsdale DJ (2002) Mortality and growth of juvenile hard clams Mercenaria mercenaria during brown tide. Mar Biol 141:1045-1050

Harris GP (1980) The measurement of photosynthesis in natural populations of phytoplankton. Stud Ecol 7:129-187

Jones MN (1984) Nitrate reduction by shaking with cadmium: alternative to cadmium columns. Water Res 18:643-646

Kahler P, Koeve W (2001) Marine dissolved organic matter: can its C:N ratio explain carbon overconsumption? DeepSea Res I 48:49-62

Kana TM, Glibert PM (1987) Effect of irradiances up to $2000 \mu \mathrm{E} \mathrm{m}^{-2} \mathrm{~s}^{-1}$ on marine Synechococcus. Deep-Sea Res 34:497-516

Keller AA, Rice RL (1989) Effects of nutrient enrichment on natural populations of the brown tide phytoplankton Aureococcus anophagefferens (Chrysophyceae). J Phycol 25:636-646

Kirchman DL, Suzuki Y, Garside C, Ducklow HW (1991) High turnover rates of dissolved organic carbon during a spring phytoplankton bloom. Nature 352:612-614.

Krempin DW, Sullivan CW (1981) The seasonal abundance, vertical distribution, and relative microbial biomass of chroococcoid cyanobacteria at a station in southern California coastal waters. Can J Microbiol 27:1341-1344

Kudo I, Harrison PJ (1997) Effect of iron nutrition on the marine cyanobacterium Synechococcus grown on different N sources and irradiances. J Phycol 33:232-240

LaRoche J, Nuzzi R, Waters R, Wyman K, Falkowski PG, Wallace DWR (1997) Brown tide blooms in Long Island's coastal waters linked to variability in groundwater flow. Global Change Biol 3:397-410

Lively JS, Kaufman Z, Carpenter EJ (1983) Phytoplankton ecology of a barrier island estuary: Great South Bay, New York. Estuar Coast Shelf Sci 16:51-68

Lonsdale DJ, Cosper EM, Kim WS, Doall MH, Divadeenam A, Jonasdottir SH (1996) Food web interactions in the plankton of Long Island bays, with preliminary observations on brown tide effects. Mar Ecol Prog Ser 134:247-263

MacIsaac EA, Stockner JG (1993) Enumeration of phototrophic picoplankton by autofluorescence microscopy. In: Kemp PF, Sherr BF, Sherr EB, Cole JJ (eds) Handbook of methods in aquatic microbial ecology. Lewis Publishers, London, p $187-197$

Mague TH, Friberg E, Hughes DJ, Morris I (1980) Extracellular release of carbon by marine phytoplankton: a physiological approach. Limnol Oceanogr 25:262-279

Mulholland MR, Gobler CJ, Lee C (2002) Peptide hydrolysis, amino acid oxidation and $\mathrm{N}$ uptake in communities seasonally dominated by Aureococcus anophagefferens. Limnol Oceanogr 47:1094-1108

Newell CR, Shumway SE, Cucci TL, Selvin R (1989) Effects of natural seston particle size and the type of feeding rates, feeding selectivity, and food resource availability for the mussel Mytilus edulis at bottom culture sites in Maine. J Shellfish Res 8:187-196

Parsons TR, Maita Y, Lalli CM (1984) A manual of chemical and biological methods for seawater analysis. Pergamon Press, New York 
Ryther JH (1954) The ecology of phytoplankton blooms in Moriches Bay and Great South Bay. Biol Bull 106: 198-209

Ryther JH, Dunstan WM (1971) Nitrogen, phosphorus, and eutrophication in the coastal marine environment. Science 171:1008-1013

SCDHS (Suffolk County Department of Health Services) (1985-2000) Office of Ecology's annual reports of water quality in the Peconic Estuary. SCDHS, Riverhead, NY

Sieracki ME, Keller MD, Cucci TL, Their E (1999) Plankton community ecology during the bloom initiation period of the brown tide organism Aureococcus anophagefferens in coastal embayments of Long Island, N.Y. EOS Trans Am Geophys Union 80:285

Smayda TJ (1990) Novel and nuisance phytoplankton blooms in the sea: evidence for a global epidemic. In: Graneli E, Sundstrom B, Edler L, Anderson DM (eds) Toxic marine phytoplankton. Elsevier, New York, p 29-40

Editorial responsibility: Edna Granéli,

Kalmar, Sweden
Waterbury JB, Watson SW, Valois FW, Franks DG (1986) Biological and ecological characterization of the marine unicellular cyanobacterium, Synechococcus. Can Bull Fish Aquat Sci 214:71-121

Valderrama JC (1981) The simultaneous analysis of total nitrogen and phosphorus in natural waters. Mar Chem 10: 109-122

Williams PJLeB (1995) Evidence for the seasonal accumulation of carbon-rich dissolved organic material, its scale in comparison with changes in particulate material and the consequential effect on net $\mathrm{C} / \mathrm{N}$ assimilation ratios. Mar Chem 51:17-29

Wilson RE, Wong KC, Carter HH (1991) Aspects of circulation and exchange in Great South Bay. In: Schubel JR, Bell TM, Carter HH (eds) The Great South Bay. State University of New York Press, Albany, p 9-22

Yentsch CS (1980) Light attenuation and phytoplankton photosynthesis. Stud Ecol 7:95-127

Submitted: June 5, 2003; Accepted: November 11, 2003

Proofs received from author(s): March 16, 2004 